\title{
Modular Construction vs. Traditional Construction: Advantages and Limitations: A Comparative Study
}

\author{
Karthik Subramanya ${ }^{1}$, Sharareh Kermanshachi ${ }^{2}$ and Behzad Rouhanizadeh ${ }^{3}$
}

1 Department of Civil Engineering, University of Texas at Arlington, Arlington, USA, karthik.subramanya@mavs.uta.edu

2 Department of Civil Engineering, University of Texas at Arlington, Arlington, USA, sharareh.kermanshachi@uta.edu

3 Department of Civil Engineering, University of Texas at Arlington, Arlington, USA, behzad.rouhanizadeh@mavs.uta.edu

\begin{abstract}
Modular construction is a novel technique that has several advantages over traditional construction methods; however, along with the benefits, there are limitations that make it challenging. Various aspects of modular construction need to be studied in-depth to improve the construction process, and the aim of this study was to accomplish that by investigating its advantages and limitations and comparing them with traditional construction. The advantages were identified through a thorough literature review, and were classified into five categories: project schedule, project cost, labor safety, project quality and productivity, and environmental. The limitations were also investigated through the existing literature and classified into five categories: project planning, transportation, public and expert acceptance, establishment cost and cost due to complexity, and coordination. The results revealed that the advantages of modular construction outnumber its limitations; however, further technological development and research would lessen or mitigate the challenges. The results of this study highlight the main benefits and challenges associated with modular construction and will help project stakeholders choose between this method and conventional construction methods for their projects.
\end{abstract}

(c) 2020 The Authors. Published by Budapest University of Technology and Economics \& Diamond Congress Ltd Peer-review under responsibility of the Scientific Committee of the Creative Construction Conference 2020.

Keywords: modular construction, traditional construction, modularization

\section{Introduction}

The Construction Industry Institute (CII) [2] defines modular construction as "the use of offsite construction (including a segregated area onsite) and includes all work that represents substantial offsite construction and assembly of components and areas of the finished project." Implementation of modular construction has notably increased throughout the past several decades [1]. Projects improve in several areas, such as cost, schedule, safety, etc. when this method is properly utilized. The experts broadly accept that modularization will lead to significantly enhanced productivity in the construction industry in the next 20 years [3]; nonetheless, several challenges and barriers to proper implementation limit its use in some cases [4].

During the past few decades, researchers have studied different aspects of modular construction. Pasquire and Gibb [5] studied the advantages and challenges of off-site production of construction components and revealed that experience plays the most important role in deciding whether to use modular or traditional construction. Song et al. [6] developed a tool with which the decision makers could evaluate the feasibility of modularization in their projects. Choi [7] investigated the relationship between the factors that may impact the success of a modular construction project and the project productivity and indicated that there 
is a reasonable correlation between them. O'Connor et al. [8] revealed that when a construction project has a time constraint, modularization can be a useful method for completing the project in the allotted time. The most important challenges pertained to delays in the assembly of the components, overproduction, and long lead times.

Despite the fact that several researches have focused on different aspects of modular construction, few studies have compared the characteristics of traditional and modular construction to provide a guideline for deciding which method is best for a specific project. This study aims to identify the advantages and disadvantages of modular construction and compare them with those of traditional construction in a descriptive manner. The outputs of this research point will assist stakeholders in whether to use traditional or modular construction methods for a project.

\section{Methodology}

Relevant documents of different types were collected from the existing literature. The documents were obtained from four main databases: Google Scholar, ResearchGate, Scopus, and Science Direct. Keywords such as modularization, modular homes, modular vs traditional, prefab construction, off-site manufacturing, and others were used to explore various search engines. The content of the collected documents was analyzed with regard to title of the journal, nature of the study, year of research, need for modular construction, identification of factors contributing to the project success/failure, and data collection practices. The advantages associated with the implementation of the modular method of construction were identified and classified into categories of project schedule, project cost, labor safety, project quality and productivity, and environmental. The limitations of modularization in construction were identified and classified into categories of project planning, transportation, public and expert acceptance, establishment cost and cost due to complexity, and coordination.

\section{Content analysis}

The content of the documents used in this study was analyzed according to (1) title of the journal, (2) data collection practices, (3) research objectives, (4) year of research, and (5) need for modular construction. In the following, all of the content analysis stages are described.

\subsection{Title of the journal}

Over 80 journal articles, conference papers, dissertations, and research reports were examined. Approximately $50 \%$ of the documents were journal articles, followed by conference papers, guidebooks, dissertations, and project reports. Table 1 shows the list of journals and the number of collected articles from each.

Table 1. List of journals and the number of collected articles from each

\begin{tabular}{lcc}
\hline \multicolumn{1}{c}{ Journal Title } & Frequency & Percentage \\
\hline Journal of Construction Engineering and Management & 8 & 12 \\
Journal of Cleaner Production & 3 & 5 \\
Journal of Management in Engineering & 3 & 5 \\
Project Management Journal & 3 & 5 \\
Journal of Engineering, Design and Technology. & 3 & 5 \\
Automation in Construction & 2 & 3 \\
Procedia Engineering & 2 & 3 \\
Journal of Injury Control and Safety Promotion & 2 & 3 \\
Journal of Architectural Engineering & 2 & 3 \\
Other Journals and papers & 34 & 55 \\
\hline Total Distribution of studied literature based on data collection method & 100 \\
\hline \multicolumn{2}{c}{ (Combination merview and questionnaire, literature review and case study, etc.) }
\end{tabular}




\subsection{Data collection practices}

Figure 1 shows the distribution of the studied literature, based on data collection method used. As is shown in the figure, the data collection method most often used (48\%) was exclusively from a literature review. Twenty-one percent (21\%) of the data was from case studies, $9 \%$ was from surveys, and the remaining $22 \%$ combined the three methods to collect data.

\subsection{Research objectives}

Figure 2 illustrates the distribution of the studied documents according to their objective. Sixty-two percent (62\%) of the studied literature focused on determining the advantages and promoted the wide use of modular construction. Eighteen percent (18\%) of the documents concentrated on finding and discussing the limitations, and twenty percent (20\%) of them examined both the advantages and limitations and suggested further research due to unavailability of data.

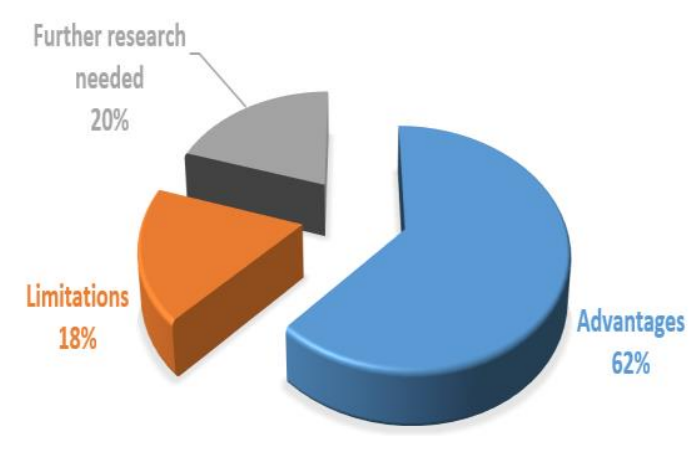

Figure 2. Distribution of documents according to their objective

\subsection{Year of study}

As shown in Figure 3, the number of journal articles published on the advantages of modular construction from 1995 to 2020 increased exponentially, which conveys that the need for modular housing has become more critical during the past two decades. Between 2015 and 2020, 36 journal articles were published on this topic, which was the highest number of studies among all five-year targeted intervals.

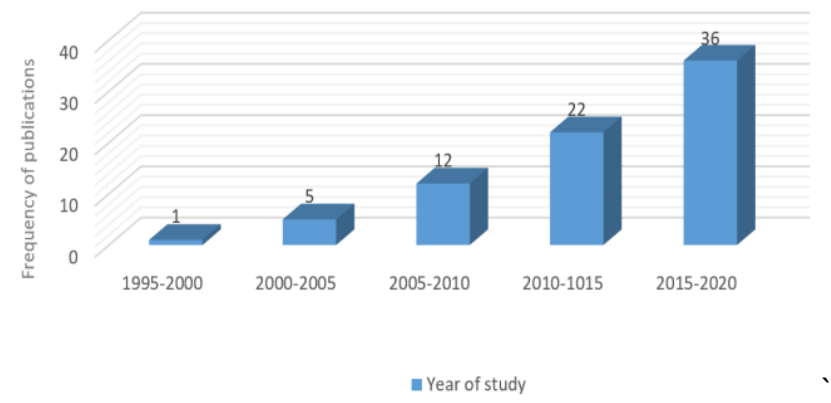

Figure 3. Distribution of publications on modular house based on year and frequency

\subsection{Need for modular construction}

After a careful review of the journal articles, it was found that two key factors influence the need for modular construction: (1) population growth, and (2) a high rate of deaths resulting from construction work.

\subsubsection{Population growth and need for affordable housing}

Data provided by the U.S. Census projects that the population in the United States is expected to grow from 300 million people today to over 350 million people by the end of 2025. Based on the average household (2.59 people per household), 19.3 million homes will be needed to accommodate the extra 50 million people. Many studies indicate that urbanization is influenced by housing factors [13]. Cities are not growing proportionately with the economy, and there is a gap between the upper and lower classes. This division 
can be addressed with proper housing for every class of people, which includes living in an environment that is healthy, affordable, and feasible [14]. Based on a survey in 2005, every third person in cities live in inconvenient and unsanitary conditions [15].

\subsubsection{High rate of deaths in traditional construction}

The construction industry has a higher rate of death than all of other sectors of work. In the U.S, nearly $20 \%$ of deaths result from the construction sector (OSHA). Klakegg [16] espoused that construction jobs at offsite plants are safer than on-site operations, as the majority of accidents occur on the construction premises. All of the information available in the Safety Hazards to Workers in Modular Home Construction video pertains to residential construction and does not differentiate between modular and mobile homes [17]. With the same deficiencies in data, [14] the Occupational Safety and Health Administration database contains reports of 125 accidents related to modular building construction, most of which occurred during installation processes and were caused by falls from roofs [16]. It is estimated that $80 \%$ fewer accidents occur from modular construction than from traditional construction [16]. Responses from a survey conducted by Becker [18] showed that $50 \%$ of the responders believed that modularization is safer than traditional construction.

\section{Advantages and limitations of modular construction}

Modular construction has several advantages and disadvantages that need to be considered while using this method [19]. Many of the advantages are related to improvements in costs, schedules, safety, quality, productivity, environmental performance, etc. [20], while the disadvantages are associated with project planning, transportation and site limitations, initiation costs, lack of knowledge, etc. [10]. These considerations are discussed in the following, based upon information derived from the literature.

\subsection{Advantages}

The advantages of modularization and the sources of the information are summarized in Table 2 and discussed in the following. In general, by carefully implementing modular construction methods, there are several advantages in broad areas such as quality, labor, cost, speed of construction, and environmental impacts.

Table 2. List of the advantages of modularization in construction and the sources of information

\begin{tabular}{ll}
\hline \multicolumn{1}{c}{ Advantage } & \multicolumn{1}{c}{ Source(s) } \\
\hline Speedy & {$[10] ;[19] ;[20] ;[21] ;[22]$} \\
Cost effective & {$[2] ;[23] ;[24] ;[25] ;[26] ;[27]$} \\
Highly Safe & {$[28],[29],[30],[31],[32]$} \\
Highly Productive & {$[33] ;[34] ;[35]$} \\
Environmentally Friendly & {$[21] ;[36] ;[37] ;[38] ;[39] ;[40]$} \\
\hline
\end{tabular}

Speedy: Two Important benefits of the modularization method for construction are that several activities can be performed simultaneously [21], and weather conditions have little effect on the schedule [19]. As a result, the time required to complete a modular construction project is usually $40 \%$ less than that of traditional construction methods [19], which can be very important for projects with a need for a quick turnaround [41], such as such as post-disaster reconstruction of infrastructures, hospitals, etc. [42]. Ramaji and Memari [20] indicated that the complexity of a project considerably affects the time-saving feature of modularization, due to the increased need for communication and on-site work [22].

Cost Effectiveness: CII [2] revealed that a 10\%-25\% decrease in the construction cost of projects is expected when modularization is implemented. Several factors contribute to the lower cost $[15,16]$, such as reduced material transportation for on-site labor [17], the highly efficient installation of construction components produced off-site, and the lack of vulnerability to weather extremes [18]. Cartwright [19] emphasized that modular construction leads to lower costs because the design procedure is standardized and requires less time and engineering than the traditional design process. 
Highly Safe: Working on-site often involves activities that threaten the safety of the workers [28,43], and the increasing number of fatalities and non-fatal injuries have led many researchers to look for solutions [29]. Several studies have investigated the effects of modularization on the safety of the laborers and revealed that it results in a significant decrease in the number of safety problems [30]. The rate of accidents occurring in construction projects reduces by $80 \%$ when the modular construction method is used [31]. Even though modularization usually decreases the rate of injuries at job sites, safety frameworks need to be established for this method as well [31]. Thus, the Occupational Safety and Health Administration (OSHA), which monitors the on-site injuries in the U.S., provided requirements for the safety of the laborers who work on projects that implement modular construction [32].

Highly Productive: The production of prefabricated components for modular construction is tightly controlled and mostly automated [33]. The laborers who produce the components are skillful if for no other reason than they repeatedly perform the same procedure $[44,45]$. In addition, the components are not subjected to weather conditions that might affect the quality of the materials [34]. In summary, the modular products have the potential to be of higher quality, less expensive, and produced in higher quantities in a smaller time period than those produced at the construction site [35].

Environmentally Friendly: The amount of waste generated by traditional construction methods has always been an environmental challenge for project managers and stakeholders [36]. Modular construction generates less waste than traditional construction [21], the products are easy to reuse and recycle, the waste is easy to dispose of [38], the components may be detached when their lifecycle ends [39], they don't produce on-site dust, greenhouse gases, or noise 140], etc. Thus, modular construction is a sufficient solution to the need for reducing the volume of waste [36,37].

\subsection{Limitations}

The limitations of modularization in construction and the sources of the information are summarized in Table 3 and discussed in the following.

Table 3. List of the limitations of modularization in construction and the sources

\begin{tabular}{ll}
\hline \multicolumn{1}{c}{ Limitation } & \multicolumn{1}{c}{ Source(s) } \\
\hline Required Accurate Planning & {$[46] ;[47] ;[48]$} \\
Transportation Challenges & {$[46] ;[49] ;[50]$} \\
Negative Public and Expert Perception & {$[51] ;[52]$} \\
Establishment Cost and Cost Due to Complexity & {$[4] ;[19] ;[10] ;[51] ;[53]$} \\
Excessive Coordination Needed & {$[54] ;[55]$} \\
\hline
\end{tabular}

Require Accurate Planning: O'Connor et al. [46] indicated that the project planning process of modular construction differs approximately $37 \%$ from the project planning of conventional construction. The differences might include the overall planning, cost estimation, scoping, design, etc. [46], which lead to considerable limitations. In addition, the planning process is especially challenging because of the complex components that have to be produced and assembled during the prefabrication process [47]. Thus, accurate planning with explicit scope and design details is required prior to the start of the project [48].

Transportation Challenges: An adequate number of vehicles is required to deliver the manufactured components to the jobsite for modular construction [49]. Oversized components need specific transportation considerations and cause delays, incur extra costs, and add complexity to the construction process [50]. The transportation limitations of modular construction are barriers to the timeliness and cost effectiveness of such projects [46].

Negative Public and Expert Perception: Overall, the concept of modular construction is viewed negatively by the public and even some of the construction experts [51]. This will have to change before it is widely used, and for this change to occur, the public will need to be made aware of its positive aspects [52]. 
Establishment Cost and Cost Due to Complexity: Even though the cost of construction is less for an off-site construction method, it requires the establishment of a fabrication plant [19]. Therefore, in areas where the labor and other requirements for traditional construction cost less than establishing a manufacturing plant for modular construction, on-site construction is more popular with the project stakeholders [51]. Modular construction requires suppliers, contractors, designers, and engineers who are experienced in and knowledgeable about prefabricated construction [4], and the lack of such experts is a considerable constraint to implementing this method [19]. Since many financial documents cannot be accessed, some researchers have expressed doubts about the positive impact of modularization on the cost of the construction projects [53]. For example, Kamali and Hewage [10] espoused that since modular construction is a relatively new and complex construction method, a wide range of studies need to be conducted to determine the costs. In addition, the modularization process needs to be monitored appropriately to correlate the timesaving factors with cost effectiveness.

Excessive Coordination Needed: In any construction project, establishing coordination and transitioning from one stage of construction to the next is key to completing the project on schedule and cost effectively $[56,57,58,59,60,61]$. Presumably, since the procedure in modular construction is different, the need for coordination will be a greater challenge $[54,55]$.

\section{Discussion}

Among the five major advantages of modular construction over traditional construction, the cost and schedule, which determine the productivity of a project [61], are interrelated. Saving time in construction activities equates to reducing the cost of the project [10]. Some aspects of these factors, however, such as the cost of materials, which is estimated to be lower than those used in traditional construction because they can be bought in bulk, independently impact modular construction $[2,62,63]$. Another example is the time that is required to design a modular project, which is significantly less than for traditional construction, because the designs are typically used for multiple similar projects $[46,64]$.

Safety is of high importance in any construction project, and data shows that modular construction is safer than traditional construction methods [65]. Much of the improved safety is due to the reduced environmental hazards in off-site manufacturing [2]. The safe and less hazardous environment also enhances productivity and the quality of the products [54].

The planning, cost estimation, scoping, and design in modular construction are different from those of traditional construction and have their own challenges and limitations that are likely to affect the whole planning process $[47,66]$. In addition, the prefabricated components need special consideration when being delivered to the jobsite, which can affect the timeliness and cost effectiveness of a project [48]. In traditional construction, however, such challenges are not observed [67]. The probable extra costs incurred by using modular construction are the initial setup cost, lack of available skilled workers, and the complexity of the process [4,68]. The general disagreement about modularization [69] and the difficulties of coordinating the staff remain as impediments to this method being used more broadly. In summary, according to the studied literature on modular construction, although there have been improvements in several of the features of this technique, there are still opportunities for more $[25,69]$. 


\section{Conclusion}

Various aspects of modular construction technique were investigated in this study, and the positive and negative features were discussed as advantages and limitations. The major advantages discussed included project schedules, project costs, safety of the laborers, project quality and productivity, and environmental. The major limitations included project planning, transportation, public and expert acceptance, establishment cost and cost due to complexity, and coordination.

The results revealed that although modular construction has more advantages than limitations, further research is needed to mitigate or eliminate the challenges. The outputs of this study will be of benefit to project stakeholders who are trying to decide whether to use modular or traditional construction methods for their projects.

\section{References}

[1] Choi, J.O., Chen, X. B., \& Kim, T. W. "Opportunities and challenges of modular methods in dense urban environment". International journal of construction management, 19(2), 93-105, 2019. https://doi.org/10.1080/15623599.2017.1382093

[2] Construction Industry Institute (CII). "Transforming modular construction for the competitive advantage through the adaptation of shipbuilding production processes to construction", 2011

[3] National Research Council. "Advancing the competitiveness and efficiency of the US construction industry". National Academies Press, 2009

[4] Enshassi, M. S., Walbridge, S., West, J. S., \& Haas, C. T. "Integrated risk management framework for tolerance-based mitigation strategy decision support in modular construction projects". Journal of Management in Engineering, 35(4), 05019004, 2019. https://doi.org/10.1061/(asce)me.1943-5479.0000698

[5] Pasquire CL, Gibb AGF. "Considerations for assessing the benefits of standardization and pre-assembly in construction". Journal of Finance Manage Prop Constr. 7(3):10., 2002

[6] Song J, Fagerlund WR, Haas CT, Tatum CB, Vanegas JA. "Considering prework on industrial projects". Journal of Construction Engineering Management. 131(6):723-733, 2005. https://doi.org/10.1061/(asce)0733-9364(2005)131:6(723)

[7] Choi, J.O. "Links between modularization critical success factors and project performance". Ph.D. Dissertation, Austin (TX): The University of Texas at Austin, 2014

[8] O'Connor JT, O'Brien WJ, Choi J.O. "Standardization strategy for modular industrial plants". Journal of Construction Engineering and Management. 141(9):4015026, 2015. https://doi.org/10.1061/(asce)co.1943-7862.0001001

[9] M. Arif and Charles Egbu. "Making a case for offsite construction in China". Engineering Construction \& Architectural Management 17(6):536-548, 2010. https://doi.org/10.1108/09699981011090170

[10] Kamali, M., \& Hewage, K. "Development of performance criteria for sustainability evaluation of modular versus conventional construction methods". Journal of cleaner production, 142, 3592-3606., 2017. https://doi.org/10.1016/j.jclepro.2016.10.108

[11] Arashpour M, R Wakefield, E.W.M Lee, R.W.K Chan, M R Hosseini. "Analysis of interacting uncertainties in on-site and off-site activities: Implications for hybrid construction". International Journal of Project Management 34(7), 2016. http://doi.org/10.1016/j.ijproman.2016.02.004

[12] Joseph Neelamkavil. "Automation in prefab and modular construction industry". $26^{\text {th }}$ international symposium on automation and robotics in construction, 2009. https://doi.org/10.22260/isarc2009/0018

[13] Ahmed W.A Hammad, A A Nezhad, D Rey. "A Comparison of Mixed Integer Programming Models for the Construction Site Layout Problem". 32nd International Symposium on Automation and Robotics in Construction and Mining, 2016. http://doi.org/10.22260/ISARC2015/0109

[14] Elena M.Generalova, Viktor P.Generalov, Anna A.Kuznetsova. "Modular Buildings in Modern Construction". Procedia Engineering Volume 153, 2016. https://doi.org/10.1016/j.proeng.2016.08.098

[15] J Goulding, F P Rahimian, M Arif Mark sharp. "New offsite production and business models in construction: priorities for the future research agenda". Architectural Engineering and Design Management 11(3), 2014. https://doi.org/10.1080/17452007.2014.891501

[16] Klakegg, O. "Modern Construction Management". Construction Management and Economics, 31(12),.1215-1217, 2013. https://doi.org/10.1080/01446193.2013.867519

[17] Salama T, Salah, A, Moselhi, O. and Al-Hussein, M. "Near optimum selection of module configuration for efficient modular construction". Automation in construction, 83, 316-329, 2017. https://doi.org/10.1016/j.autcon.2017.03.008

[18] Becker, Paul \& Fullen, Mark \& Takacs, Brandon. "Safety Hazards to Workers in Modular Home Construction". 2003

[19] Ferdous, W., Bai, Y., Ngo, T. D., Manalo, A., \& Mendis, P. "New advancements, challenges and opportunities of multi-storey modular buildings-A state-of-the-art review". Engineering Structures, 183, 883-893, 2019. https://doi.org/10.1016/j.engstruct.2019.01.061

[20] Ramaji, I. J., \& Memari, A. M. "Interpreted information exchange: Systematic approach for BIM to engineering analysis information transformations". Journal of Computing in Civil Engineering, 30(6), 2016. https://doi.org/10.1061/(asce)cp.1943-5487.0000591

[21] Kawecki, L. R. "Environmental performance of modular fabrication: calculating the carbon footprint of energy used in the construction of a modular home". PhD thesis, Arizona State University, 2010

[22] Ramaji, I. J., \& Memari, A. M. "Information exchange standardization for BIM application to multi-story modular residential buildings". In AEl 2015 (pp. 13-24), 2015. https://doi.org/10.1061/9780784479070.002

[23] Kozlovská, M., Kaleja, P., \& Struková, Z. "Sustainable construction technology based on building modules". In Advanced Materials Research 10(41), 231-234, Trans Tech Publications Ltd, 2014. https://doi.org/10.4028/www.scientific.net/amr.1041.231

[24] Navaratnam, S., Ngo, T., Gunawardena, T., \& Henderson, D. "Performance review of prefabricated building systems and future research in Australia". Buildings, 9(2), 38. 2014. https://doi.org/10.3390/buildings9020038

[25] Choi, J.O., O'Connor, J. T., \& Kim, T. W. "Recipes for cost and schedule successes in industrial modular projects: Qualitative comparative analysis". Journal of Construction Engineering and Management, 142(10), 2016. https://doi.org/10.1061/(asce)co.19437862.0001171

[26] Austin, R. B., Pishdad-Bozorgi, P., \& de la Garza, J. M. "Identifying and prioritizing best practices to achieve flash track projects". Journal of Construction Engineering and Management, 142(2), 2016. https://doi.org/10.1061/(asce)co.1943-7862.0001061

[27] Cartwright, J. T. "Zoning and designing for affordability using modular housing". Master thesis. USA: lowa State University, 2011

[28] Golabchi, A., Han, S., Seo, J., Lee, S., \& Al-Hussein, M. "An Automated Biomechanical Simulation Approach to Ergonomic Job Analysis for Workplace Design." Journal of Construction Engineering and Management,2015. http://doi.org/10.1061/(ASCE)CO.19437862.0000998, 04015020. 
[29] Li, X., Han, S., Gül, M., Al-Hussein, M., \& El-Rich, M. "3D visualization-based ergonomic risk assessment and work modification framework and its validation for a lifting task". Journal of Construction Engineering and Management, 144(1), 2015. https://doi.org/10.1061/(asce)co.1943-7862.0001412

[30] Ahn, S., Han, S., \& Al-Hussein, M. "Recovery time analysis of back muscle fatigue in panelized residential modular construction factory". Modular and Offsite Construction (MOC) Summit Proceedings, 1(1), 2016. https://doi.org/10.29173/mocs28

[31] Peñaloza, G. A., Formoso, C. T., \& Saurin, T. A. "Resilience skills used by front-line workers to assemble precast concrete structures: an exploratory study". Ambiente Construído, 17(4), 25-43, 2017. https://doi.org/10.1590/s1678-86212017000400183

[32] U.S. Department of Labor. "Fatality and catastrophe investigation summaries". Retrieved from https://www.osha. gov/pls/imis/accidentsearch.html, 2014

[33] Jiang, L., Li, Z., Li, L., \& Gao, Y. “Constraints on the promotion of prefabricated construction in China”. Sustainability, 10(7), $2516,2018$. https://doi.org/10.3390/su10072516

[34] Cameron, P. J., \& Di Carlo, N. G. "Piecing together modular: understanding the benefits and limitations of modular construction methods for multifamily development". Doctoral dissertation, Massachusetts Institute of Technology, 2007

[35] Ambler, S. "Briefing: Off-site construction of a new nuclear laboratory at Dounreay, Scotland". Proceedings of the Institution of Civil Engineers-Energy, 166(2), 49-52, 2013. https://doi.org/10.1680/ener.11.00036

[36] Illankoon, I. C. S., \& Lu, W. "Cost implications of obtaining construction waste management-related credits in green building". Waste Management, 102, 722-731, 2020. https://doi.org/10.1016/j.wasman.2019.11.024

[37] Wang, J., Li, Z., \& Tam, V. W. "Critical factors in effective construction waste minimization at the design stage: a Shenzhen case study, China". Resources, Conservation and Recycling, 82, 1-7, 2014. https://doi.org/10.1016/j.resconrec.2013.11.003

[38] Li, X. X., \& Li, G. L. "Exploration of modular build of architectural space". In Applied Mechanics and Materials. Trans Tech Publications Ltd. 357, 338-344, 2013. https://doi.org/10.4028/www.scientific.net/amm.357-360.338

[39] Lu, N., \& Korman, T. "Implementation of building information modeling (BIM) in modular construction: Benefits and challenges". In Construction Research Congress: Innovation for Reshaping Construction Practice. 1136-1145, 2010. https://doi.org/10.1061/41109(373)114

[40] Amiri, A., Caddock, P., \& Whitehead, M. "Accounting for the greenhouse gas emissions of construction: a UK case study". In Proceedings of the Institution of Civil Engineers-Civil Engineering 166(2), 82-88, 2013. https://doi.org/10.1680/cien.12.00040

[41] Kamali, M., \& Hewage, K. "Life cycle performance of modular buildings: A critical review". Renewable and sustainable energy reviews, 62, 1171-1183, 2016. https://doi.org/10.1016/j.rser.2016.05.031

[42] Safapour, E., and Kermanshachi, S. "Investigation of the Challenges and Their Best Practices for Post-Disaster Reconstruction Safety: Educational Approach for Construction Hazards". Transportation Research Board 99th Annual Conference, 2019

[43] Mostafa Namian, Kermanshachi S, Mohammad Khalid, Ahmed Al-Bayati. "Construction Safety Training: Exploring Different Perspectives of Construction Managers and Workers". 2020 ASEE Annual Conference \& Exposition, 2020

[44] Kermanshachi S, Thakur R, Govan P. "Discovering the impact of late change orders and rework on labor productivity: a water treatment case study analysis using system dynamics modeling". Construction research congress, 2018. https://doi.org/10.1061/9780784481295.069

[45] Kermanshachi S, Rouhanizadeh B. "Sensitivity Analysis of Construction Schedule Performance Due to Increased Change Orders and Decreased Labor Productivity". 7th CSCE International Construction Specialty Conference (ICSC), 2019.

[46] O'Connor, J. T., O’Brien, W. J., \& Choi, J. O. "Industrial project execution planning: Modularization versus stick built”. Practice periodical on structural design and construction, 21(1), 2016. https://doi.org/10.1061/(asce)sc.1943-5576.0000270

[47] Li, Z., Shen, G. Q., \& Xue, X. "Critical review of the research on the management of prefabricated construction". Habitat international, 43, 240-249, 2014. https://doi.org/10.1016/j.habitatint.2014.04.001

[48] Aarseth, W., Ahola, T., Aaltonen, K., Økland, A., \& Andersen, B. "Project sustainability strategies: A systematic literature review". International Journal of Project Management, 35(6), 1071-1083, 2017. https://doi.org/10.1016/j.ijproman.2016.11.006

[49] National Modular Housing Council (NMHC). Builder's guide to modular home set-up and completion. Report, Arlington. VA,USA, 2017.https://www.manufacturedhousing.org/wp-content/uploads/2017/01/Builders-Guide-to-Modular-Home-Set-Up-Completion.pdf [assessed April 2020].

[50] Wei, Y., Wang D. F., Liu, J. Y., Yu, C. L., Cheng, T., \& Zhang, D. G. "Modularization technology development prospects". In Applied Mechanics and Materials. Trans Tech Publications Ltd. 509, 92-95, 2014. https://doi.org/10.4028/www.scientific.net/amm.509.92

[51] Rahman, M. M. "Barriers of implementing modern methods of construction". Journal of management in engineering, $30(1), 69-77,2014$.

[52] Wu, P., Xu, Y., Jin, R., Lu, Q., Madgwick, D., \& Hancock, C. M. "Perceptions towards risks involved in off-site construction in the integrated design \& construction project delivery". Journal of cleaner production, 213, 899-914, 2019. https://doi.org/10.1016/j.jclepro.2018.12.226

[53] Sendanayake, S. V., Thambiratnam, D. P., Perera, N., Chan, T., \& Aghdamy, S. "Seismic mitigation of steel modular building structures through innovative inter-modular connections". Heliyon, 5(11), 2019. https://doi.org/10.1016/j.heliyon.2019.e02751

[54] Hu, X., Chong, H. Y., Wang, X., \& London, K. "Understanding stakeholders in off-site manufacturing: a literature review". Journal of Construction Engineering and Management, 145(8), 2019. https://doi.org/10.1061/(asce)co.1943-7862.0001674

[55] Bendi, D., Rana, M. Q., Arif, M., Goulding, J. S., \& Kaushik, A. K. "Understanding off-site readiness in Indian construction organisations". Construction Innovation, 2020. https://doi.org/10.1108/ci-02-2020-0016

[56] Kamalirad, S., and Kermanshachi,S., Shane J, Anderson S. "Assessment of construction projects' impact on internal communication of primary stakeholders in complex project”. 6th CSCE/CRC International Construction Specialty Conference, 2017

[57] Kamalirad S, Kermanshachi S. "Development of project communication network: A new approach to information flow modeling". Construction Research Congress (CRC) 2018. http://doi.org/10.1061/9780784481271.042

[58] Kamalirad, S., and Kermanshachi,S. "Development of Project Life Cycle Communication Ladder Framework Using Factor Analysis Method". Construction research congress, 2018. https://doi.org/10.1061/9780784481301.054

[59] Safapour E, Kermanshachi S, Kamalirad S, D Tran. "Identifying effective project-based communication indicators within primary and secondary stakeholders in construction projects". Journal of Legal Affairs and Dispute Resolution in Engineering and Construction 11(4), 2019. http://doi.org/10.1061/(ASCE)LA.1943-4170.0000332

[60] Safapour E, Kermanshachi S, Kamalirad S. "Development of the effective communication network in construction projects using structural equation modeling technique". ASCE International Conference on Computing in Civil Engineering,2019. https://doi.org/10.1061/9780784482438.065

[61] Nipa T J, Kermanshachi S, Kamalirad S. "Development of effective communication framework using confirmatory factor analysis technique". ASCE International Conference on Computing in Civil Engineering, 2019. https://doi.org/10.1061/9780784482438.073

[62] Kermanshachi S. "Decision making and uncertainty analysis in success of construction projects". PhD dissertation, 2016.

[63] Kermanshachi S, B Dao, J Shane, S Anderson. "Uncertainty analysis of procurement phase performance indicators using extreme bounds analysis (EBA)". 6th CSCE/CRC International Construction Specialty Conference, 2017.

[64] Mohammadreza H, Kermanshachi S, Safapour E. "Engineering, procurement and construction cost and schedule performance leading indicators: state-of-the-art review". Construction Research Congress, 2018. https://doi.org/10.1061/9780784481271.037 
Proceedings of the Creative Construction e-Conference (2020) 012

Available online at e-2020.creative-construction-conference.com/proceedings/

[65] Nnaji, C., Gambatese, J., Karakhan, A., \& Osei-Kyei, R. "Development and Application of Safety Technology Adoption Decision-Making Tool". Journal of Construction Engineering and Management, 146(4),2020. https://doi.org/10.1061/(asce)co.1943-7862.0001808

[66] Kermanshachi S, Anderson S, P Goodrum, T R B Taylor. "Project Scoping Process Model Development to Achieve On-Time and OnBudget Delivery of Highway Projects". Journal of the Transportation Research Board, 2630(1), 2017. http://doi.org/10.3141/2630-18.

[67] Kermanshachi S. "US multi-party standard partnering contract for integrated project delivery". Master Thesis, 2010.

[68] Kermanshachi S, Bac Dao, Rouhanizadeh B, J shane, S Anderson. "Development of the project complexity assessment and management framework for heavy industrial projects". International Journal of Construction Education and Research 16(1), 2018. https://doi.org/10.1080/15578771.2018.1499568.

[69] Correia, J. M., Sutrisna, M., \& Zaman, A. U. "Factors influencing the implementation of off-site manufacturing in commercial projects in Western Australia". Journal of Engineering, Design and Technology, 2020. https://doi.org/10.1108/jedt-09-2019-0246 